\title{
ЛИТЕРАТУРОВЕДЕНИЕ
}

\author{
В.П. Перевалов
}

\section{ИСТОК «УТАЁННОЙ ЛЮБВИ» А.С. ПУШКИНА}

\begin{abstract}
Аннотация. Статья посвящена рассмотрению одной из самых интригующих и дискуссионных тем творческой жизни величайшего Поэта. В ней продолжается обоснование и развитие авторской версии понимания сути «утаенной любви» А.С. Пушкина к О.С. Потоикой-Нарышкиной, выдвинутой для обсуждения в монографии «Примерь-ка, Золушка, наряд поэзии чудесный», два фрагмента из которой опубликованы в данном журнале: «И месяи с правой стороны» (Ушаковский альбом (весна). 2011. № 4; «Ужели имя найдено?». 2013. № 1).

Анализ первоисточников (законченных и незавершенных произведений Пушкина, их черновых вариантов, графики, надписей и помет в рабочих тетрадях опирается на результаты последних текстологических изучений рукописей, а также учитывает различные интерпретаџии данной проблемы в пушкинистике. Это позволяет автору с немалой долей вероятности предложить новаторское решение поставленной задачи.

В свою очередь, обретенная «разгадка» становится основанием выявления скрытых связей между произведениями Поэта, разделенных годами жизни, жанрами, существенно изменившейся общественно-политической обстановкой. Кризисный перелом в пушкинском антропоэзисе предстает как утрата гармонии в первичном мыслеобразе «Любви-Свободы»». Случайно ли это?
\end{abstract}

Ключевые слова: А.С. Пушкин, поэзис, мыслеобраз, «Поцелуй», любовь, тайна, дружба, свобода, графика, зеркало.

\section{Статья посвящена поиску истока страсти нежной Поэта, известной как «утаённая любовь»}

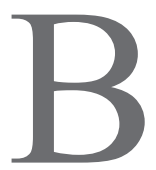
августе 1823 г. в Одессе Пушкин признался новому приятелю поэту В.И. Туманскому, что многие места в его поэме «Бахчисарайский фонтан» связаны с женщиной, в которую он был очень долго и очень глупо влюблён». Строки в элегии «Погасло дневное светило (август - сентябрь 1820 г.) отсылают к ещё более раннему времени страданий милой сердцу безотрадной, «безумной любви». Периодом томительного обмана желаний и надежд оказывается, таким образом, 1817-1820 гг., а местом Санкт-Петербург.

Воспоминания современников говорят о многих увлечениях молодого поэта-повесы, но о Любви Единственной молчат и думать не думают. Недаром она (если была фактом биографии, ибо некоторые исследователи полагают ее лишь эстетической маской, литературной игрой) Утаенная. Отсюда и обилие предположений пушкинистов, верящих в реальность глубокого и возвышенного чувства Поэта, о возможных претендентках на роль Царицы его души.

Ответ же может дать только исповедь Пушкина, содержащаяся в его произведениях, особенно первых слоях черновиков к ним, где - давно замечено - биографическая основа просматривается отчетливее. Важнейшие сведения о чувствах и мыслях Поэта, волновавших его в процессе творчества, доносят до нас его рисунки.

Вышесказанное выдвигает на первый план внимательнейшее рассмотрение рабочей тетради Пушкина ПД 829. Это так называемая Лицейская тетрадь (ЛТ), первую часть которой (л. 1-41 об) заполняют стихотворения, написанные в Лицее (по июнь 1817), а во второй части (л. 42-92 об.) доминируют черновики поэмы «Руслан и Людмила» среди стихотворений послелицейского периода (до высылки Пушкина из столицы в начале мая 1820). Открытое (прилюдное) увлечение Пушкина кн. Е.И. Голицыной в его первом светском сезоне 1817/18 гг., ее прямое обозначение в «Донжуанском списке» суживает поле поиска NN.

В начале второй части ЛТ на л. 46 находится рисунок «Поцелуй» с подписью на французском языке "le baiser» с датой: «1818/15 Dec<ember>.” Ниже и левее основного рисунка к нему сделан набросок - та же композиция меньшего размера, видимо, предварительная.

В книге Р.Г. Жуйковой юноша на этом рисунке атрибутирован как автопортрет (№3) Пушкина ${ }^{1}$. С.В. Дени-

\footnotetext{
1 Жуйкова Р.Г. Портретные рисунки Пушкина. Каталог атри-
} буций. СПб., 1996. С. 33. 


\section{Литературоведение}

сенко, автор 2 части совместной с С.А. Фомичевым книги о графике Пушкина, считает, что данный рисунок«одна из ученических штудий ... Скорее всего, это копия с чьего-то рисунка - принадлежащего, возможно, более успевающему лицеисту»².

Биографическая значимость «Поцелуя» в двух приведенных интерпретациях крайне противоположна. По мнению С.В. Денисенко «копия» никак не связана с жизненными реалиями Пушкина (или она сродни связи между дядькой в Киеве и бузиной в огороде). Напротив, изображение себя в качестве целуемого девой младой говорит о каком-то важном успехе в отношениях с прелестным полом.

Я согласен с точкой зрения Р.Г. Жуйковой.

С чего бы через полтора года после окончания Лицея Пушкину понадобилось перерисовывать «шедевр» «скотобратца»? Или дата под рисунком не соответствует времени его появления в рабочей тетради? Можно ли установить точную дату? Сомнительно и то, что копирование с образца нуждалось в предварительном наброске композиции (предкопии слева и ниже основной). Где сам оригинал? (Обычно они находятся, чему немало свидетельств приведено в данном исследовании графики Пушкина С.В. Денисенко).

Даже если установят правильное время и оригинал с именем преуспевающего автора (лицеиста?), то обнаружится, что сам вопрос остается вопросом: почему Поэт нарисовал (перерисовал) именно «поцелуй» и поставил точную дату. «Красным днем» принято фиксировать событие, т.е. возводить происходящее в жизни в ранг сверхобычного, непреходящего в текущем, запоминать особенно важное, редкое, может быть, неповторимое, одно-разовое, уникальное.

Возможно, позиция С.В. Денисенко продиктована малым иконографическим сходством юноши на рисунке с молодым Пушкиным, с другими его автопортретами той поры. Тут есть заметные «колебания» в похожести автопортрета №3 («Поцелуй») с №1 и №2 ${ }^{3}$. Да не это, на мой взгляд, главное.

Решающим в рисунке представляется передача (весьма и весьма удавшаяся) состояния высшего довольства, вернее, наивысочайшего блаженства юноши. От прикосновения (первого, едва начавшегося) губ девушки (наверняка, и от предвкушения того, что вот-вот заветное томительное желание свершится) он переполнен такого самодовольства, которое ни толики

2 Денисенко С.В., Фомичев С.А. Пушкин рисует. Графика Пушкина. СПб.: НОТА БЕНЕ; Нью-Йорк: Туманов \& К, 2001. C. 140 .

3 Жуйкова Р.Г. Портретные рисунки Пушкина. Каталог атрибуций. СПб., 1996. С. 33.

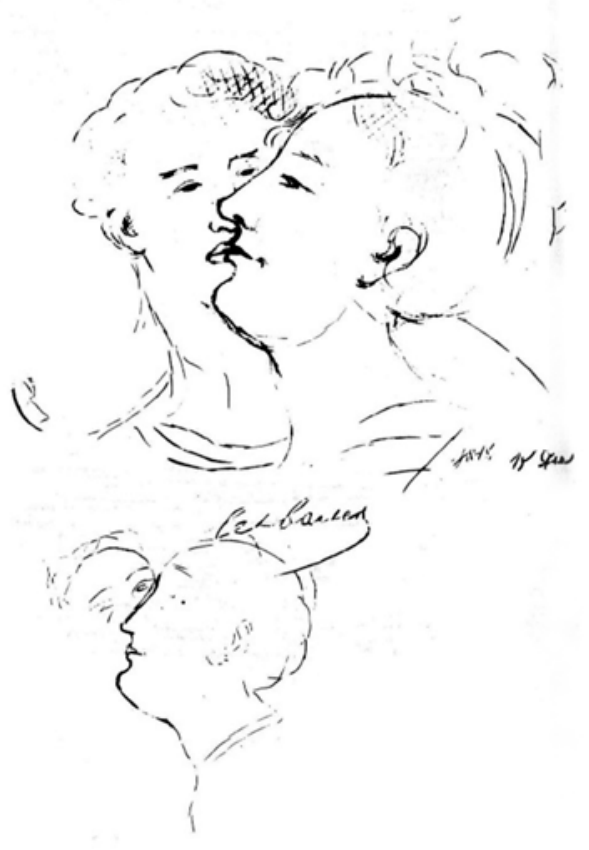

не уступит Нарциссу, безмерно влюбленному в свое отражение. Это его Триумф, пик Любви, в коем слилось земное и небесное.

Чудо первого поцелуя, пожалуй, могло бы вызвать подобный восторг у впервые целующихся влюбленных, но Пушкин-то прошел гусарскую «школу», второй светский сезон предается всем увеселениям «рассеянной» (разгульной) жизни. Затруднение очень серьезное. Но преодолимое. Если придать должное значение тому, что

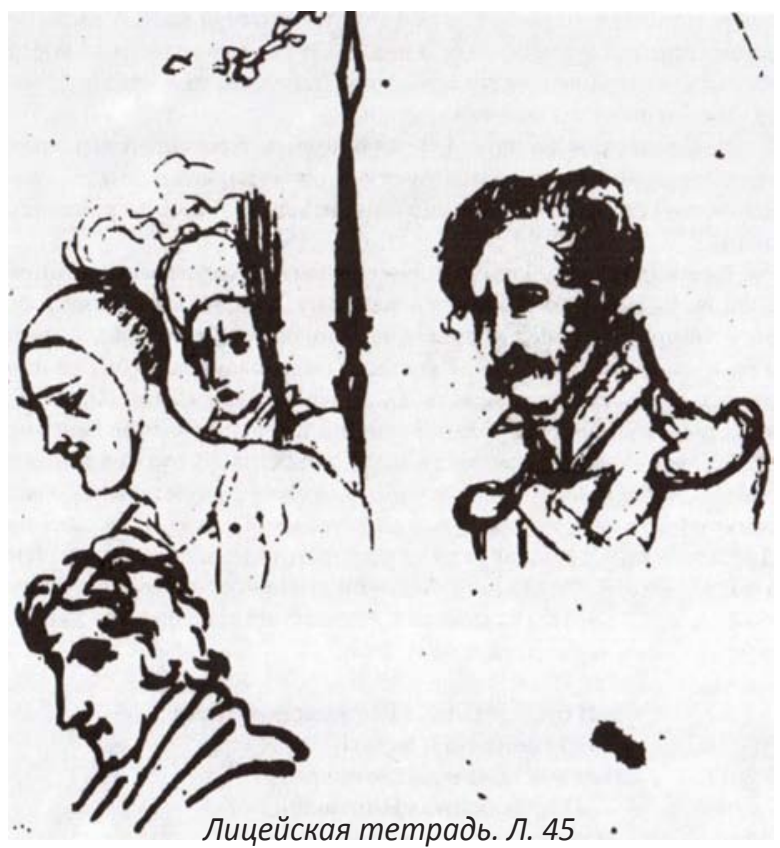




\section{Филология: научные исследования 2 (10) • 2013}

позиция юноши в данном случае «пассивна». Он страстно целовал многих «вакханок» и многими «смелыми» целован. Однако пылал без любви, сильной и возвышенной. Теперь же ждет, бесконечно ждет поцелуя от молоденькой девушки, скорее всего, первого в ее жизни. Она сама, добровольно и по собственной инициативе (в сознании и головокружении) может-должна его поцеловать. В знак ее верной, первой и единственной Любви к своему избраннику на всю жизнь, земную и посмертную. Ее же поцелуй знак обоюдопронзающий, навек скрепляющий его обет вечного служения их Любви. Его словесные признания обретают необратимость клятвы в Ее цветущей поцелуем благосклонности. Отныне и навеки вечные Поэт - «невольник чести беспощадной», «витязь беспримерный» прекрасной Дамы.

Активность девы, ее первое начальное действие в кульминационный момент в композиции «Поцелуй» находит соответствия в «Руслане и Людмиле». Застенчив, робок в замке 12 дев (и в бане, и в спальне) Ратмир, оказавшийся в нем по песенному зазыву его обитательниц. Муж-жених Руслан сохраняет целомудренность отношений с женой-невестой, хотя спящая Людмила истомно-нежно шепчет его имя. Коварный трус Фарлаф не посягает на честь бесчестно захваченной им княжны, «вознесясь» по слову Владимира в женихи его дочери. Даже в отступлении о соблазнившей автора «пастушке» (и весьма откровенном черновом наброске к этому эпизоду «Недавно тихим вечерком...») инициатива принадлежит «слабой» половине: поза (чуть более приличия обнаженная ножка?) притворившейся спящей девы вводит юношу в соблазн, а бездействие, несопротивление первому, второму, третьему поцелуям «сжигают мосты» безудержной страстью соития.

Неровность поведения, робость Поэта в общении, когда он увлекался по-настоящему, отмечена мемуаристами (А.П. Керн, С.Н. Гончаров). Ненасилие со стороны «сильного» пола - и, когда он знает и/или не знает, что любим, и когда имеет формально-юридические права на исполнение супружеского долга) - отсутствие малейшего принуждения другой стороны необходимо для сохранения свободы в Любви и Ее и Его. Без свободоволия любящих любовь сладкий плен, рабство безволия для одного, а то и для обоих. Доверие инициативы той стороне, которую традиция исстари определяла «пассивной», «объектной», думается представляет собой не только личные черты молодого Пушкина, но и принципиальную установку его антропоэзиса. Сущностно иначе обстоят дела в отношениях со жрицами Киприды, где все заранее предопределено, хотя, быть может, и не куплено. Есть «свобода любви» (так называемая - чтобы фиговым листиком красивых звонких слов прикрыть срам, хоть както - псевдоформально - оправдаться в разврате) и есть
«Свобода в Любви», воление непринуждения любимого любящим, встречная гармония свободных инициатив.

Не так прост повеса пылкий, если он размышляет образно о союзе Свободы и Любви в его различных, нераздельных и полностью неслияных ипостасях.

15 декабря 1818 г. - день счастливейший: взаимное признание в Любви, клятвенное Слово витязя, запечатленное (запечатанное) добровольным поцелуем Дамы на его устах. Союза их чувств, известный только влюбленным, больше никому в мире.

Не исключено, что непохожесть лиц участников (лицо целующей скрыто профилем юноши примерно на треть), стилизация характерных особенностей каждого в «типовых» обликах входило в исполнительский замысел автора рисунка. Знают только двое посвященных, от любопытствующих «открещивает» несходство копий с оригиналами ${ }^{4}$.

Значимость события подчеркивает выделенность рисунка на л. 46 в ЛТ. До него, после л. 45 два листа вырваны, л. 46 об. - чистый; л.46а - корешок вырванного листа. С листа 47 начинаются черновики «Руслана и Людмилы» и стихотворений. На открытом, расчищенном пространстве «Поцелуй» воздвигнут как отовсюду видный памятник.

Рубежной вехой, первой кульминацией «утаенной любви» стала клятва верности, подтверждавшая и скреплявшая взаимность, восторженное счастье Любви. Как в песне «С чего начинается Родина» из кинофильма «Щит и меч»: «... с той клятвы, которую в юности ты в сердце своем ей принес».

Погружаясь в проблему «утаенной любви», я довольно скоро отметил для себя этот рисунок, атрибутированный Р.Г. Жуйковой как пушкинский автопортрет. Но кто она? - оставалось загадкой.

Следующая деталь добавилась нескоро. Из стихотворения «Кокетке» (1821) засело в памяти, что «вечная любовь живет едва ли три недели ${ }^{5}$. Прибавим к 15 дека-

\footnotetext{
4 Так часто приятели не очень умелого рисовальщика, попытавшегося изобразить себя, глядя на получившийся портрет юноши, говорят: «ты непохож». Возражение автора, что он увековечил не себя, нисколько их не убеждает: «нет ты, но не похож».

${ }^{5}$ Перечитывая стихотворение позднее, в контексте накопившихся знаний и свете выдвинутой версии «утаенной любви», я с удивлением прозрел в нем детальное описание волнующей меня темы. В наряде насмешливого отвержения «покойных рыцарей любовь» представлена как глубоко знакомое (лично пережитое ранее?) страстное чувство. Адресат, А.А. Давыдова, не забыта Пушкиным в Донжуанском списке: «Аглая». Напрашивается предположение, что в отповеди кокетке отразилась какая-то важная сторона и очередная веха в развитии «утаенной любви» Поэта, что требует специального анализа. Вообще проблема женского кокетства волновала его (см., напр., письма к жене) до конца жизни.
} 


\section{Литературоведение}

бря 21 день и получим 5 января. Крещенский сочельник. Время гаданий. Так в поисках NN появилось неясное предвестие Татьяны Лариной. Однако отсутствие у нее райских недель с Евгением Онегиным ставит под большущее сомнение ее главный прототип в качестве претендентки на царствование в «утаенной любви», по крайней мере, до признания Пушкина: в августе 1823 г.: «был влюблен».

Тайна неустанно влечет, манит неожиданной новизной откровений неизвестного, выходящих вон из всех рядов знаемого и ожидаемого. Перепроверялись уже предложенные в пушкинистике кандидатки на эту роль, суть которой оставалась недостаточно ясна. То одна, то другая Красавица казалась достойной коронования, но что-то меня не устраивало (может быть, ускользающий от четкого понимания смысл проблемы); критическая сторона несогласных авторов перевешивала аргументы того (тех), кто отстаивал свою протеже.

Еще одним приобретением (непонятно, насколько значимым для решения проблемы, поскольку как целое оно ускользало) можно считать косвенное подтверждение, что безоблачные отношения влюбленных длились около трех недель со дня Триумфа и Клятвы в их первом светском сезоне. Во втором сезоне 1819/1820 гг. они сильно ухудшились, если не оказались на грани полного

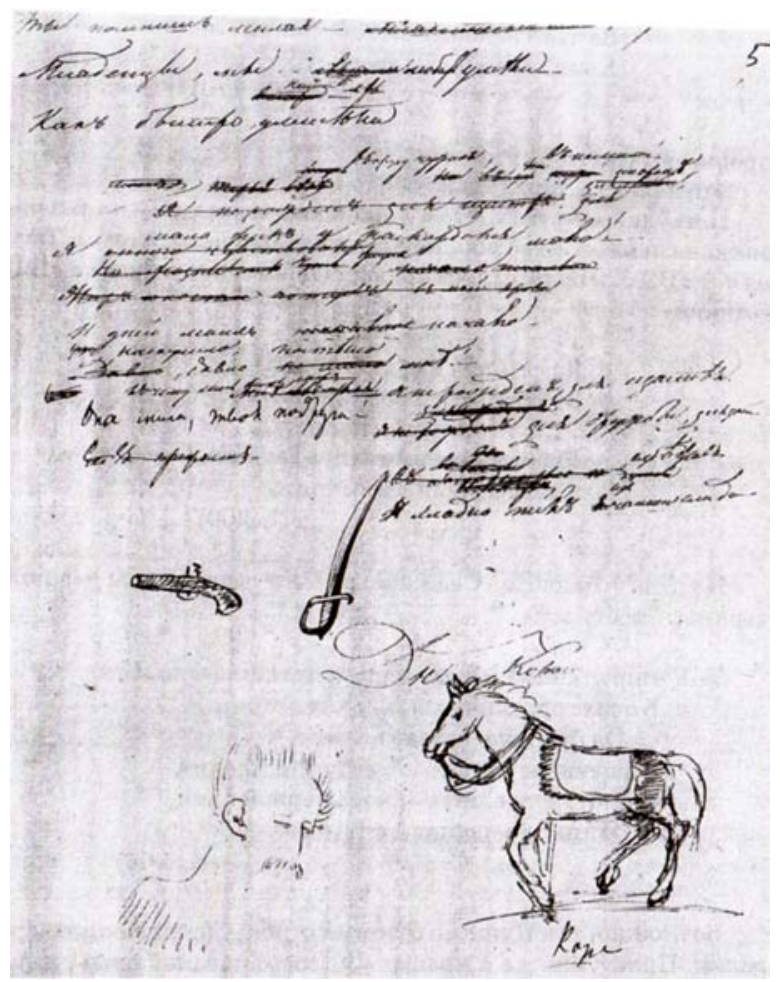

Лицейская тетрадь. Л. 45 об

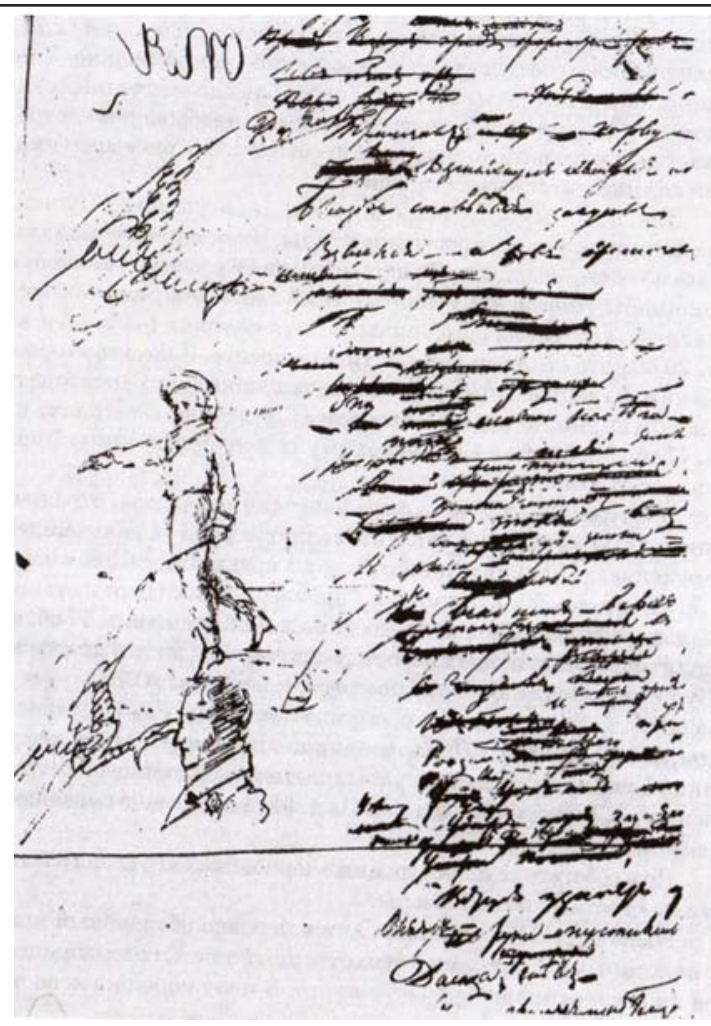

Лицейская тетрадь. Л. 47 об

и безвозвратного разрыва. 5 января 1820 г. датируется стихотворение: «Я верю: я любим; Для сердца нужно верить...» Автор незамедлительно отправил его в печать («Невский зритель». 1820, ч. 1, январь). Пушкин «молнировал» в «Дориде» свое кредо, сделал все возможное, чтобы обращение не прошло Ею незамеченным. Вторая его публикация в «Новостях литературы» (1823, NXXXIV) вновь указывает на весомость для Поэта быть услышанным Ею на рубиконной для «утаенной любви» переправе. - Что стало очевидно уму, сильному задним числом. Суть проявляется на поверхности в деталях, казалось бы чисто технических дробностях).

«Элегия» (К Кагульскому памятнику), включенная в контекст силового поля «утаенной любви», подсказывала, что 30 марта 1819 г., т.е. в первый сезон, Пушкин пережил оживление надежд, возрождение светлых перспектив Любви, прошедшей испытания на прочность.

Но имя Ее оставалось неизвестным. Это лишало поиски определенной направленности и, главное, доказательности аргументов, которая могла обрести силу лишь опираясь на реальность, историческую и биографическую. Без имени живой женщины решение проблемы круг за кругом вертелось на месте, а бесплодие тупика склоняло к признанию ее псевдо-проблемой. 


\section{Филология: научные исследования 2 (10) 2013}

Своей наглядностью и общеизвестностью решение полуторавековой проблемы пушкинистики было для меня ошеломительно. Пушкин прямо и просто назвал в «Евгении Онегине» (гл. 2, XXIII) ту, которую Любил: Ольга. Ее очень милый портрет читатель верно найдет в любом романе. (В связи с рис. На л. 46 ЛТ. Слова «портрет» и «роман» приобретают дополнительный смысл, тайный и противоположный утверждаемому. Роман не «любой», а сокровенный, Единственный). Надоел «Портрет» безмерно (безмерно несовпавший с оригиналом в самых вернейших упованиях), ибо в дни написания XXIII строфы осенью 1823 г. Ольга Потоцкая стала женой генерала Льва Александровича Нарышкина.

С определившимся именем героини исследование «утаенной любви» качественно преобразилось, вступило в существенно иную стадию. Проверка, подтверждение или опровержение гипотезы нацелились на увязывание биографии и творчества Поэта с биографией Ольги Станиславовны ${ }^{6}$.

Появилась возможность поиска самых первых следов «утаенной любви», исследование оказалось перед композицией «Поцелуй». За Пушкиным, «Вперед, вперед, моя исторья!»

Среди каллиграфических опытов Поэта в ЛТ, согласно С.А. Фомичеву, один «особенно любопытен: на л. 47 об. На полях черновика, описывающего стычку Рагдая с Фарлафом, Пушкин выводит в зеркальном отражении имя «ОЛЯ», — возможно, это воспоминание о «жрице наслаждения» Ольге Массон, которой в 1819 г. Пушкин напишет послание «Ольга, крестница Киприды...»; она же упоминается в черновике стихотворения «Веселый пир» на л. 54. На л. 92 имеется еще смазанная помета: «che're Olinka»?.

Предположение маститого исследователя с моей версией не согласуется и представляется мне не обоснованным. Близлежащие к указанному листу листы 46-49 заполнялись во второй половине декабря 1818 г., что устанавливается по дебюту Колосовой 30 декабря в роли Моины в трагедии Озерова «Фингал». Черновой автограф «О ты, надежда нашей сцены...», посвященный этому событию в ее артистической жизни, находится на л. 49. Стихотворения, связанные с Ольгой Массон появятся через несколько месяцев. Была ли сия «вакханка» дорога Поэту к концу того же 1819 г. нуждается в конкретном изучении. Правда, уменьшительноласкательное именование настраивает более «против»,

\footnotetext{
${ }^{6}$ Подробнее см.: Перевалов В.П. Примерь-ка, Золушка, наряд поэзии чудесной. М., 2011.

7 Денисенко С.В., Фомичев С.А. Пушкин рисует. Графика Пушкина. СПб.: НОТАБЕНЕ; Нью-Йорк: Туманов \& К, 2001. С. 18.
}

чем «за» 23-х летнюю «крестницу Киприды», жрицу «бесчисленных мятежных заблуждений» ${ }^{8}$.

Но как соотнести 2 песнь «Руслана и Людмилы» с именем Оля, необычно начертанным, при том каллиграфически! И причем тут зеркало?

Ключ предлагаемого решения дали размышления С.А. Фомичева над рисунками Поэта в ЛТ на л. 45 и л. 45 об. Под последними стихами черновика неоконченной элегии «Позволь душе моей открыться пред тобою» <воодушевляющая строка - В.П.> «появляются зарисовки сабли и пистолета, но прежде Пушкин чуть ниже обвел чернилами контур офицера-кавалериста (только им разрешалось носить усы) по проступившей с лицевой стороны листа прориси этого изображения, выполненного там карандашом ${ }^{9} \gg$. Нарисованный на лицевой стороне л. 45 отразился, как в зеркале, на оборотной стороне того же листа.

Имя «ЯЛО» на л. 47 об. читается «ОЛЯ» на лицевой его стороне (если сделать прорись). А на л.46 девушка целует юношу, распираемого от блажи (сверхблаженства) самодовольства. Л. 46 об. чист, а на большом поле слева, в верху листа 47 тайно для непосвященных старательно-каллиграфически! - выгравировано имя целующей Девы: «ОЛЯ». Воля-неволя, доля Поэта с 15 декабря 1818 г. Возможно, что л. 46а вырван, чтобы «безымянный» рисунок тайно имел точное имя.

Почти все лицеисты, согласно С.А. Фомичеву, сызмальства осваивали виртуозные росчерки-птицы, у Пушкина они наиболее часто встречаются среди рисунков. Первый из подобных росчерков, уже вполне освоенный, по странному сближению, встречается как раз на л. 47 об. под именем «ЯЛО». Второй на том же листе ниже касается мужского портрета в профиль, атрибутированного как Н.М. Карамзин (Жуйкова Р.Г. №399 - первое изображение Поэтом историка).

Под «Посвящением» (из черновика которого взята формула «утаенная любовь») поэмы «Полтава» (1828) стоит дата «27 октября». В контексте предлагаемой мной гипотезы и проделанного в ее интенциях анализа, есть основания предположить, что обозначенная дата совсем не случайна. Учитывая таинственно-символическую привязанность Пушкина к числам, свойственное ему верование в расчисленность жизни по календарю и его изумительно точную память на все важное, случившееся в прошлом, есть основания считать 27 октября годовщиной начала «утаенной любви». Сто лет истории государства приравнивались Поэтом 10

\footnotetext{
8 Черейский Л.А. Пушкин и его окружение. Л.: Наука, 1988. C. 256.

9 Денисенко С.В., Фомичев С.А. Пушкин рисует. Графика Пушкина. СПб.: НОТАБЕНЕ; Нью-Йорк: Туманов \& К, 2001. С. 13.
} 


\section{Литературоведение}

годам в жизни человека. Если и тут дело обстоит также, то Пушкин напоминал Ольге об их встрече в далеком, очень далеком 1818 г. Тогда Оленьке исполнилось 16 лет (любимый девичий возраст Поэта - не с тех ли пор?). Месяц и день рождения О. Потоцкой мне неизвестен (в доступных справочниках только год - 1802). Судя по нареченному имени девочка появилась на свет в июле 11 (или около) числа - день именин равноапостольной, великой княгини Ольги (в крещении Елены), первой женщины-правительницы Руси. Историческая Ольга родом псковитянка, т.е. землячка Пушкина. Псков - очаг свободы на Руси, согласно историческим взглядам современников Поэта. Числа 7 и 11 входят в знаменитое беспроигрышное карточное трио «Пиковой дамы» (1833). У Пушкина есть рисунок рака, предположительно знак Зодиака - еe (по крайней мере, в том числе ${ }^{10}$. Поэт по Зодиаку Близнец).

В самом конце того же юбилейного 1828 г. Пушкин в Москве впервые увидит 16-летнюю Наталью Гончарову. Когда она станет его женой, ее первый выход в Большой свет Санкт-Петербурга состоится в воскресенье 25 октября 1831 г. На следующий Д.Ф. Фикельмон записала в дневнике, что Наталья Николаевна необыкновенно красива, и «муж говорит, что она умна. Что до него, то он перестает быть поэтом в ее присутствии; мне показалось, что он вчера испытывал ... волнения, какие чувствует муж, желающий чтобы его жена имела успех в свете ${ }^{11} \gg$.

А 10 лет назад в октябре 1818 г. молодой Пушкин начинал свой второй светский сезон. Бурный поток любовного увлечения прошлого сезона княжной Авдотьей, протекавший прилюдно, успокоился в стабильном русле дружбы, уважения к ее «неженским» высоким интересам и свободе женских мнений и суждений в них. Вскоре в близком окружении Поэта констатируют, что он в Голицыну уже не влюблен. (Возможно, в летнее межсезонье Александр встречался с Жозефиной Велио. После Лицея, как и в нем, характер их общения остался прежним (может быть, эмоции стали, особенно с его стороны, чуть сдержаннее): разговоры о литературе являли «ум, вкус верный и нравов чистоту» собеседницы, но ее чувства страсти нежной отданы были все также не ему. Интеллектуальная составляющая не складывалась в гармоничное целое с любовными порывами Поэта, опыт («сын ошибок трудных») склонял его в сторону необязательности глубокого и обширного, сильного и богатого ума у

${ }_{10}$ Пушкин А.С. Большое академическое собрание сочинений: в 16 т. Т. 18, дополнительный. Рисунки. М., 1996. С. 361.

11 Летопись жизни и творчества Александра Пушкина: в 4-х т. М.: Слово, 1999. Т. 3. С. 404.
Возлюбленной, хотя, конечно, и не отсутствия его вовсе. Правда и то, что отвлеченные рассуждения, теория «вообще» - вотще, ничто в пламени пылких страстей, сжигающих «я» реально, по-настоящему (см. «Мечтателю»).

Итак, сердце Поэта, получившее первый жизненный закал, к новому светскому сезону было свободно, томимо жаждой Любви. 27 октября среди знакомых лиц он вдруг заметил новенькую юную незнакомку. Черты лица, весь облик и грациозные движения её казались впорхнули в петербургскую залу со страниц модного романа. Вгляделся пристальнее. Ужель та царскосельская девчушка? А как похорошела! Только-только начинает расцветать... Сомнений нет- с ней рядом сестра и мать, Софьи обе. Да, да, меньшую Олей звать.

В последний год обучения в Лицее предвыпускники встречались на литературно-танцевальных вечеpax с детьми жителей Царского села, среди которых готовились к явлению в Большом свете и две дочери статс-дамы Софьи Константиновны Потоцкой, вдовы польского магната Станислава Потоцкого. Старшей Софии в ту пору было 15-16 лет, младшей Ольге 15 лет исполнится в июле 1817, когда первые выпускники покинут - наконец-то - «монастырь», а Потоцкие уедут весной из столицы по своему обычному летнему маршруту: Тульчин, Одесса, Крым. Сестры Софья и тем более подросток Ольга не привлекли «взрослого» Александра, его эротический интерес сосредотачивался на вполне расцветших прелестницах — молодой вдове А. Смит и, вероятно, на Жозефине Велио. Знакомство и общение, учтивое, лёгкое, не привязывающее, скорее всего, было. В незаконченном наброске среди черновиков первых строф «Евгения Онегина» (ПД 834 Л.6 об. Датируется 29 мая -5 июня 1823). Пушкин обращается к Ольге Потоцкой ${ }^{12}$ :

«Скажи - не я ль тебя заметил

В толпе застенчивых подруг,

Твой первый взор не я ли встретил,

Не я ли был твой первый друг?»

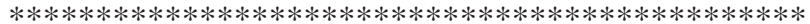

Рассмотрим черновики стихотворений, расположенные в ЛТ (ПД 829) рядом с рисунком «Поцелуй. 1818/15 декабря» (л. 46), предположив в нем фиксацию кульминационного события.

Л. 42 об. «К...»

12 Установление адресата обращения и причин его вызвавших см. в указанной выше монографии «Примерь-ка, Золушка...». 


\section{Филология: научные исследования 2 (10) 2013}

Счастлив, кто близ тебя, любовник упоенный,

Без томной робости твой ловит светльй взор. Движенья милье, игривый разговор

И след ульбки незабвенной 13 .

Полистовое описание ЛТ: «Беловой автограф на л. 42 об. «В перевернутом положении тетради запись рефрена “Је t'aime tant...» (Я так люблю тебя ...»фр.) из романса П.-Ж. Гара «Le delire de 1'amour» («Страдания любви») на стихи Фабра д’Эглантина» (c. 275).

Комментарии к стихотворению (с. 550-552) ни датировкой (предположительно осень 1817 - ноябрь 1818 гг.), ни источником (вторая ода Сапфо, как установил Б.В. Томашевский) не противоречат проверяемой версии. Скорее поддерживают ее половодьем чувств, нахлынувших на Поэта, который для их передачи опирается на знаменитый античный образец, более двух десятков раз поэтически переведенный и напечатанный в России с 1755 по 1810 гг. Счастливое упоение любовью в тексте стихотворения совместно с рефреном «Я так люблю тебя» указывают на начало возобновленного общения и восторг от первых успехов, еще более ошеломительный после предыдущих неудач. Т.е. на благодать ноябрьского Потопа. (Погибельной бедой «аукнется» ноябрьское наводнение 1824 г., описанное в 1833 г. в печальной петербургской повести «Медный всадник». Но что грядущее готовит...? А в ныне-на-Сто-стоящем счастлив я близ тебя, упоенный Потопом Святым).

Л. 43. «Дубравы, где в тиши свободы...» первоначальный черновой набросок; «Могущий бог садов паду перед тобой...», черновой автограф». Датируются предположительно второй половиной 1818 г.

Могущий бог садов - паду перед тобой,

Приап, тьл, коему все жертвует в при<роде>, <?>

Твой лик уродливый поставил я с мольбой

[В моем смиренном огороде,]

Не с тем, чтоб удалял ты своенравных коз

И пти[u] от $<>$ и нежных $<u>$ незрельх,

Тебя украсил я венком <из> диких роз

При пляске поселян весельх

Не с тем, чтобы...

(C. 92)

«Приап-уродливый сельский божок, страж садов, защитник и покровитель земледельцев и рыбаков, публичных женщин и развратников, кутила и сводник;

13 Пушкин А.С. Полн. собр. соч.: в 20 т. СПб.: Наука, 2004. Т. 2, кн. 1. С. 36. (Далее стр. в тексте). изображения его были распространены повсеместно: в лесах, садах, на дорогах, пристанях, публичных домах и т.д.» (с. 653). Герой наброска просит выступить бога в роли покровителя и дарителя страстной чувственной любви, радостей сладострастия. Время его готовности жертвенно пасть «при пляски поселян веселых» ориентирует на общественные праздники в честь Приапа, происходившие в марте и июне» (с. 653).

Март - рановато для северной страны, а вот летнее время в самый раз для украшения венком из диких роз античного бога героем данного наброска. Оно совпадает с событиями стихотворения «Дубравы, где в тиши свободы...». Не противоречит биографическим данным. С мая 1818 г. Пушкин, никуда не уехавший из столицы, часто посещает Карамзиных, живущих на даче в Царском Селе. Недавний «монастырь» вызывает у выпущенного год назад на свободу лицеиста совсем другие чувства: прошлое наполняется очарованием, благоговейным дыханием.

Автограф этого стихотворения находится на двух листах рабочей тетради: «л. 43 - эпиграф и первоначальный набросок ст. 1-8; л. 44 об. - перебеленный текст ст. 1-4, далее переходящий в черновой» (с. 653). Важно отметить их разную датировку: «первоначальный черновой набросок - предположительно августомноябрем 1818 г.; продолжение работы - предположительно весна (не ранее 10-х чисел марта) 1819 г.». (с. 654). «Горизонтальные разделительные штрихи в тексте автографа, а также не дающие связных чтений варианты между ст. 1-9 и 10-20, думается, прямо указывают на фрагментарность текста» (с. 656).

\section{O Zauberei der ersten Liebe!.. Wieland}

Дубравы, где в тиши свободыл
Встречал я счастьем каждый день,
Ступаю вновь под ваши своды,
Под вашу дружескую тень. -
Идля [меня] воскресла радость,
Идушу взволновали вновь
Моя потерян<ная> млад<ость>,
Тоски мучительная сладость
[И] тьл, о [первая] любовь.

$* * * * * * * * * * * * * * * * * * * * * * * * * * * * * * * * * * * * * * * * * * * * * *$
Любовник муз уединенный,
В с <ени пленительных > дубрав,
Я был свидетель умиленный
Ее младенческих забав.
Она цввела $n<e>$ редо мною, 


\section{Литературоведение}

$И<я>$ чудесной красотьл

Уже отгадывал мечтою

Еще неясные черты,

И мыслль об ней одушевила

[Моей] иевницы первый звук

И неприметно приуч $<$ ила $>$

(C. 93).

За исключением эпиграфа стихи 1-8 (первый фрагмент) описывают через новое восприятие героя исстари знакомое ему место. Во «вновь» свершается их преображение, породнение.

Текст ст. 1-8 (с. 93).

Ст. 9: «[И] ты, о [первая] любовь» перекидывает мостик к переживаниям героя, представшим любовником муз, к тому, как встреча с очень юной прелестницей превращается в чудо рождения его как истинного Поэта и ее как Музы.

В общем, в контексте предлагаемой версии «утаенной любви», первый фрагмент описывает летние впечатления героя в Царском Селе - до судьбоносной встречи Пушкина на светском балу в октябре с Ольгой (она еще на юге, в Одессе, в Крыму). Даже сгущение в данном фрагменте любовных настроений героя, сосредоточенных в эпиграфе, не может поколебать доминирования темы Любви во втором фрагменте. Устоявшемуся мнению, что прототипом героини является либо Н.В. Кочубей, либо Е.П. Бакунина (обе в главном Донжуанском списке) противоречит то, что первая давно уехала за границу, а вторая на 4 года старше Пушкина. Второй фрагмент создан в пору увлечения Поэтом «старой» знакомой, бывшей отроковницей его лицейских дней. Посвящение ей по меркам возраста наиболее правдоподобно. А коли и был еще неведомый прототип, то мельком, без заметных последствий. Переадресовка в таком случае представляется достаточно обоснованной и необходимой в горизонте развиваемой версии «утаенной любви».

В свете будущего легко просматривается связь позднего фрагмента стихотворения с приведенным выше «Скажи, не я ль тебя заметил...» (1823 г.) и с развитием темы Единственной Любви Ленского к Ольге в «Евгении Онегине» (конечно, не копирующей рабски развитие отношений Александра и Ольги в жизни).

На листах между черновиками стихотворения «Дубравы, где в тиши свободы...» в ЛТ помещены черновые автографы: л. 43 об. «К Н.Я. П<люсковой>» («На лире скромной, благородной...») и на л. 44 «Метателю» («Ты в страсти горестной находишь наслажденье...»).

О первом из них, датируемым мартом 1819 г., скажем кратко: автор «Елизавету втайне пел». В отно- шении к императрице использован глагол прошедшего времени. «Утаенная любовь» к ней (Л.Н. Васильева, С.С. Гейченко) прошла к 20-ти годам Поэта! Если и была страсть нежная юного пажа к «Величавой жене», (Л.М. Аринштейн) то миновала. Благорасположение к ней сохранилось, возможно, и возвысилось. Ибо политически эта формула означала обсуждавшийся замысел возведения супруги царя на трон как воплощенной Добродетели, которой, увы, все больше не обнаруживали в Александре I.

Как раз этой весной Пушкин с головой поглощен переводом на военную службу - именно в Тульчин, где находится штаб 2 армии и ... родовое имение Потоцких. Желание видеть «chere Olinka» часто, и в наступающее светское межсезонье, жажда прославиться в действующей на Кавказе армии отодвинули на второй план вопросы наивысшей госполитики.

Стихотворение «Мечтателю» (л. 44) в комментарии датируется не позднее ноября 1818 г. По времени выхода №51 «Сына отечества» 21 декабря (с. 531). Пора та самая.

\section{Мечтателю}

Tы в страсти горестной находишь наслажденье; Тебе приятно слезы лить, Напрасным пламенем томить воображенье И в сердие тихое уньние таить.

Поверь, не любишь ты, неопьтный мечтатель.

О если бы тебя, унылых чувств искатель,

Постигло страшное безумие любви;

Когда б весь яд ее кипел в твоей крови;

Когда бы в долгие часы бессонной ночи,

На ложе, медленно терзаемый тоской,

Tыз звал обманчивый покой,

Вотще смыкая скорбны очи,

Покровы жаркие, рыдая, обнимал

И сохнул в бешенстве бесплодного желанья,-

Поверь, тогда б ты не питал

Неблагодарного мечтанья!

Нет, нет! в слезах упав к ногам

Своей любовницьь надменной,

Дрожащчий, бледный, исступленный,

Тогда б воскликнул ты к богам:

«Отдайте, боги, мне рассудок омраченный,

Возьмите от меня сей образ роковой!

Довольно я любил; отдайте мне покой!»

Но мрачная любовь и образ незабвенный

Остались вечно бы с тобой.

(C. 31) 


\section{Филология: научные исследования 2 (10) • 2013}

«Анненков указал, что стихотворение «вызвано было любовью одного молодого человека, утверждавшего, что он не ищет взаимности и доволен чувством своим». Он и другие исследователи считали адресатом стихотворения Кюхельбекера, влюбившегося в воспитанницу Екатерининского института Екатерину Григорьевну Волконскую. «Безоговорочно отвергал эту адресацию Б.П. Городецкий, рассматривавший стихотворение как обращенное к самому себе и содержащее автополемику с элегиями 1816 г. Вопрос о наличии у стихотворения конкретного адресата нельзя считать решенным...

Стихотворение представляет собой важную литературную декларацию послелицейского Пушкина, утверждающую романтическую концепцию «любвистрасти» в противовес элегической концепции «любви-мечтательства» (с. 532). Литературно-рассудочного и созерцательного.

Искателю унылых чувств, неопытному мечтателю, рассудочно знающему любовь по литературным канонам - и только по ним и через их навязчивость переживающим коллизии действительности, Поэт противопоставляет осмысление опыта Любви как страшного безумия, бешенства бесплодного желания. Из чего следует предпочтение душевного покоя ее мрачной, безотрадной бездне. Покой, покой увы, утрачен навсегда в незабвенности Ее рокового образа.

Биографически данное стихотворение перекликается со страстным увлечением Пушкина Е.И. Голицыной, длившемся с конца 1817 г. не более года. В ответ княгиня отстояла права на ограничение общения с Поэтом, равно как и с другими мужами, чистой дружбой, поддержанием их приятельского союза высокими умственными устремлениями благого Просвещения на нивах политики, истории, науки. Не тут ли самое раннее предвестие тайного изнывания в любовных терзаниях Татьяны после отповеди-проповеди Евгения? Кстати, именно Кюхельбекер узнает в Татьяне друга Александра.

Создание «Мечтателю», как нарочно, вписывается в сроки угасания «напрасного пламени любви» к «Благожелательной», образу высокоморальному-роковому, и - роковому, первых тактов прелюдии сладостного пленения «Святой», воскрешением радужных надежд на взаимность. (Страшно, но грезится - сияющее в вечном - блаженном покое слияние сердец и душ). На обороте л. 44 расположился второй фрагмент «Дубравы, где в тиши свободы...» Райский островок невинных наслаждений.

На л. 45 запись ст. 74 и 163 первой песни «Руслана и Людмилы» (вероятно, дополнение к в общем написанной части поэмы). «Основная часть листа занята рисунками карандашом и пером.
Л.45 об. «Позволь душе моей открыться пред тобою...», черновой автограф; «Она мила, твоя подруга...» черновой набросок (одного стиха - В.П.).

Далее вырваны два листа» (с. 276).

Л. 45 об.

Позволь душе моей открыться пред тобою

И в дружбе сладостной отраду почерпнуть.

Скучая жизн $<$ жюю, томимьій суетою,

[Я жажду] близ тебя, друг нежный, отдохнуть...

Ты помнишь, милая, - зарею наших лет,

Младенцы, мы < >любить умели...

Как быстро наших лет $<>$ улетели

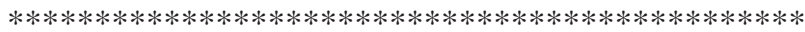

В кругу чужих, в немилой стороне,

Я мало жил и наслаждался мало!

И дней моих печальное начало

Наскучило, давно постыло мне!

К чему мне жизнь, я не рожден для счастья,

[Для радостей], для дружбы, для забав,

$<>$ избежав,

Я хладно пил из чаши сладо<страстья>.

(C. 103).

«Позволь душе моей открыться пред тобою...» датируется предположительно 1819 г. Твердых оснований для датировки нет (с. 665).

Положение в ЛТ не является однозначно датирующим признаком; запись на оставленном чистым обороте л. 45 могла быть сделана позднее декабрьских рисунков на листах 45 и 46. Однако выбор места для стихотворения среди еще незаполненных листов тетради вряд ли чисто случаен, никак не связан с окружающими черновиками, рисунками, пометами.

По палеографическим признакам (перо, чернила, почерк), отмеченным Т.Г. Цявловской, данное произведение сходно с черновым автографом стихотворения «Дорида» на л. 55об. и с записью отдельных стихов послания «Орлову» на л. 56, а также с беловым автографом последнего, имеющим дату 4 июля 1819 г., все эти автографы были отнесены к одному времени: июню, 25 - июлю, 10 того же года (с. 666).

...набросок, и по расположению на листе отчетливо делящийся на две части (ст. 1-7 и 8-15), напечатан в Акад. Как единое стихотворение с ненаписанной средней частью. Следует, однако, иметь в виду, что перед нами лишь первые попытки решения поэтической темы. При отсутствии явного представления даже об общем контуре лирического сюжета, о метрическом и строфическом рисунке стихотворения, вряд ли можно 


\section{Литературоведение}

судить и об отношении этих двух частей друг к другу. Поэтому в настоящем издании набросок представлен как состоящий из двух фрагментов, печатающихся через редакторскую разделительную черту» (с. 666).

Гипотеза, что адресат стихотворения сестра Пушкина Ольга Сергеевна «не является сколько-нибудь основательной; незавершенность текста не позволяет с определенностью судить даже о типе лирического адресата» (с. 666).

Возможность, что стихотворение обращено к иной О.С.П. — к Ольге Станиславовне Потоцкой, не исключена. Тогда оно создавалось в светское межсезонье, в ее отсутствие в Петербурге, что возвращает ему прежнюю датировку.

Потребность исповеди героя перед Возлюбленной, скорее всего, обусловлена необходимостью объяснения причин (вин) нарушения клятвы верности со жрицами Киприды, среди которых заметно выделялась «Лаиса» («Дорида» Пушкина - вариация «на тему стихотворения Батюшкова «В Лаисе нравится улыбка на устах...» («Из греческой антологии» VIII)» ${ }^{14}$. Упоение чувственной страстью опасно не только физическим заболеванием, но и разрушением в душе счастьяблаженства в Любви, недостаточно окрепшего, развившегося до «дружбы сладостной», робкой, нежно лелеющей целомудренность. Существенное различие в сладостях Любви (см. выше) внутренне обостряется, начинает осознаваться как антагонизм, взывающий к альтернативе выбора: одна услада - источник живительной отрады, другая - хладна, отчуждена от души, опустошает и мертвит ее сердечные волненья. Болезным жаром хладнокровит.

Уяснение самому себе дается сознанию тяжело, как и выздоровление идет вначале туго, нетвердо. Порыв искреннего раскаяния в собственных грехах подменяется оправданием себя путем нагнетания крайне неблагоприятных обстоятельств. Среда заедает «я», обильно используются, особенно во втором фрагменте, чужие литературные наработки. Хотя при сильном желании в стихах 13-14 можно усмотреть руду для классического объяснения Евгения Татьяне:

«Но я не создан для блаженства;

Ему чужда душа моя;

Напрасны ваши совершенства...

Их вовсе недостоин я.» (2л. 4, XIV).

Пока же в отношениях к Ней герой рассчитывает на отраду сладостной дружбы. И только? Является ли

14 Пушкин А.С. Собр. соч. в хронологическом порядке. М.: ЛМЛИ РАН, «Наследие», 2000. Т. 1. С. 496, прим. она предвестием и частью совершенного блаженства, космической гармонии небесно-земной Любви? Или осторожным шагом к примирению после ссоры, грозящей ужасом разрыва, катастрофой? Неопределенно. Автор остановился на том, что открыться ей нужно, уверив, что «хладно пил из чаши сладострастья». И не нужно спешить - необходимость исповеди наступит не по собственному хотению, а по ее повелению.

В ожидании приезда Ольги в столицу и открытия светского сезона Пушкин попытается вновь совладать с определением того, как вести себя с Ней:

«Tым мне велишь открыться пред тобою.

( ) дерзал я обо<жать?>,

Но страсть одна повелевала мною».

(C. 105).

Неудачно. Непомерно тяжко на душе: и не исповедаться в грехопадении нельзя, и исповедь из рая извергнет непременно.

В соответствии с наступившем отливом волн в Потопе «утаенной любви» не тянется перо к бумаге, стихи совсем нейдут.

Л. 46 - центр исследования рисунок «Поцелуй». Оборот л.46 чистый. Л. 46 а. Корешок вырванного листа» (с. 276). Основной массив текстов л. 47-48 черновики 2 песни «Руслана и Людмилы». На л. 47 скрытое имя «ОЛЯ» - непрорисованное начертание «ЯЛО» на л. 47 об. Отдельные зачеркнутые варианты «К молодой вдове» (л. 48 об.). Л. 49 содержит черновики той же песни поэмы, черновик послания «Колосовой», по которому устанавливается дата: после 30 декабря 1818 г. На нем же черновой автограф «Как сладостно!.. Но, боги, как опасно...», занимает верхнюю половину листа, текст (с. 94) над указанными ранее записями.

Как сладостно!.. но, боги, как опасно

Тебе внимать, твой видеть мильй взор!..

Забуду ли улььбку, взор прекрасный

И огненный < > >азговор!

Волиебница, зачем тебя я видел$<$

[Узнав тебя], блаженство я познал

И счастие мое возненавидел.

(C. 94).

«Стихотворение осталось незавершенным (не написан ст. 6 , не доведена до конца работа над ст. 4 и 7; однако, композиционно оно вполне может восприниматься и как законченное, не предполагающее продолжения сочинение в жанре «отрывка», антологической эпиграммы)». Тематически оно близко к двум другим, 


\section{Филология: научные исследования 2 (10) • 2013}

также незаконченным, стихотворениям в ЛТ - «Лаиса, я люблю твой смелый ( ) взор...» и «К...» («Счастлив, кто близ тебя, любовник упоенный...»). Все три лирические миниатюры построены как обращение к возлюбленной и более или менее ориентированы на античность; во всех, помимо тематических и композиционных, есть и лексические соответствия: повторяется одна и та же рифма («взоры-разговоры», «взор-разговор») (с. 657).

Так обстоит дело, если адресат лирического обращения неизвестен (см. там же). Поскольку имя его мной названо, ситуация существенно меняется. «Как сладостно...» и «Счастлив...любовник упоенный» обращены к Ольге Потоцкой, как и второй фрагмент «Дубравы, где в тиши свободы...» В них для блаженства любящего достаточно быть рядом с возлюбленной, глядеть на нее, слушать речи, разговаривать (прямотаки зарождение завязи писем Татьяны и Онегина друг к другу!). Тем более таить клятву верной Любви. Здесь совмещение с «Поцелуем» — точное попадание в райское яблочко.

Это превосходит счастье упоения страстью с Лаисой-«вакханкой», дарованной услышавшего мольбы Приапа.

\section{Лаиса, я люблю твой смельий, [вольный $]^{15}$ взор, \\ Неутолимый жар, открытые <?> желанья \\ И непрерывные лобзанья \\ И страсти полный разговор. \\ Люблю горящих уст я вызовы немые, \\ Восторги быстрые, живые. \\ (C. 95)}

Итак, «блаженство» следует отличать от «счастья»различие в сладостном чувстве тончайшее, недаром в более раннем из этих двух стихотворений первое отождествлено со вторым, а в третьем, исходном, их совпадение ощущается как опасность:

«[Узнав тебя], блаженство я познал

И счастье мое возненавидел».

Сладость Любви блаженной разнится от сладости упоения любви как чувственной страсти, между ними возможна и рознь-ненависть. Насколько их совпадение прочно? О, боги! Как сложна, прихотливо переменчива и незаметно изменна их природно-духовная смесь - стихия сравнительно с рассудочной дихотомией земного и

\footnotetext{
15 «Анализ черновой рукописи позволяет предположить, что эпитеты «смелый» и «вольный» варьировались Пушкиным как взаимозаменяемые» (С. 658); обычно в изданиях Акад. В том числе, они даются вместе.
}

небесного. Пушкин в поэме мастерски сортирует сласти. Отношение мужа-жениха Руслана к томно вздыхающей о нем во сне жене-невесте Людмиле кардинально отлично от отношений между Ратмиром и смелыми девами в замке. Затем в любви к пастушке восточный хан сближается с Русланом и, дорожа блаженством уединения, боится взглянуть на Людмилу.

В общем, адресуя круг произведений рубежа 1818/19 гг. Ольге Потоцкой, нельзя забывать о «Лаисе».

Далее в Лицейской тетради «Лист 49 об. чистый».

Л. 50 «Руслан и Людмила», черновые наброски, относящиеся к Песням четвертой и второй и вставка в Песнь первую.

Л. 50 об. «И я слыхал, что божий свет...», черновой автограф (с. 276).

После неровно оборванного Л. 51 / л. 51 об., где читаются остатки текста, работа над ней продолжилась на Л. 52 и далее.

И я сльхал, что Божий свет

Единой дружбою прекрасен,

Что без нее отрадын нет,

Что жизни б путь нам был ужасен,

Когда б не тихой дружбы свет.

Но слушай - чувство есть другое:

Оно и нежит и томит,

В трудах, заботах и в покое

Всегда не дремлет и горит;

Оно мучительно, жестоко,

Оно всю душу в нас мертвит,

Коль язвы тяжккой и глубокой

Елей надежды не живит...

Вот страсть, которой я сгораю!

Я вяну, гибну в ивете лет,

Но исиелиться не желаю...

(C. 33)

Кроме чернового автографа в ЛТ, л.50 об., есть второй автограф, перебеленный с поправками, на отдельном листе - ПД 27. На его обороте - черновые наброски послания (Колосовой), позволяющего вместе с палеографическими признаками предположительно датировать оба стихотворения концом декабря 1818 началом 1819 гг. (с. 542).

«Сопоставление (и часто противопоставление) любви и дружбы как ведущих человеческих страстей было обычным в моралистической философии и литературе, как русской, так и западноевропейской, еще в XVIII в.» (c. 542). «В элегической поэзии обычен мотив неудачной попытки компенсировать утрату любви заботами друзей. Пушкин развивает тему в полемике с сентиментальной традицией (с. 542-543)». 


\section{Литературоведение}

Поэт, зная — на собственном опыте - c. 542-543 все опасности и язвы любви без живительной надежды на взаимность, повышенный риск гибели в любовной буре (образы метели в кромешной и морозной тьме, всемирного потопа) исцеляться не желает. Предчувствие края бездны в упоении Любви. А уготовано ему, как мы знаем, чашу эту испить сполна. Пока же вызов принят, витязь устремился по морю Любви, по ее зыбким волнам, играющим неопределенностью.

На дворе декабрь, Рождество, Святки - вечность.

$* * * * * * * * * * * * * * * * * * * * * * * * * * * * * * * * * * * * * * * * * * * * * *$

Мыслеобраз Любви-Свободы, в котором, на мой взгляд, концентрируется заряд пушкинского антропоэзиса, в силу неразделенности, взаимопроникновения своих ипостасей должен быть представлен со стороны каждой из них, содержащей в себе свое иное как близнечно-родное. В двуединой целости, рассмотрена ипостась свободно-волящей Любви, но мысль, живая в оба-в-раз, развертывается и на оси любовного воления Свободы. В дни, близкие изображению «Поцелуя» и рассмотренные выше произведения вокруг него, Поэт создает стихотворение высочайшего гражданского, социально-политического пафоса, ставшее одним из самых любимых в среде будущих декабристов. Знаменитое послание-призыв

«К Чедаеву» («е»—- так в тексте)

Любви, надежды, тихой славы

Недолго нежил нас обман,

Исчезли юные забавы,

Как сон, как утренний туман;

Но в нас горит еще желанье;

Под гнетом власти роковой

Нетерпеливою душой

Отчизны внемлем призыванье.

Мы ждем с томленьем упованья

Минуты вольности святой,

Как ждет любовник молодой

Минуты верного свиданья.

Пока свободою горим,

Пока сердиа для чести живы,

Мой друг, отчизне посвятим

Души прекрасные порывы!

Товарищ, верь: взойдет она,

Звезда пленительного счастья,

Россия вспрянет ото сна,

И на обломках самовластья

Напишут наши имена!

(C. 35).
В нем единство двух ипостасей мыслеобраза свободно волящей, взаимной Любви и любовного волнения гражданско-политической Свободы достигают максимальной гармонии в целости блаженного счастья жизни, ее действенного смысла сверх рассудочного «я=я». Святость Союза общей (Законной) Вольности-Свободы и верной Любви всех людей как неповторимых ликов в Ней, космически движущей солнце и светила, для Пушкина имеет сокровенный смысл. Его тайна - имя-нное значение (знамение) «Святости» - Ольга. Священный Наиславнейший (Станиславовна) Потоп.

Декабристам же «уподобление жажды «вольности святой» ожиданию любовного «свидания» было чуждо их мировоззренческим и литературным установкам разделявшим «личное» и «общественное». В рассудочные дихотомии главный мыслеобраз Поэта не вписываются без упрощения - без утраты дара своего иного каждым «в себе и для себя», низводящей положительную разность между единством и целостью к нулю, а динамику изменений и движения к сумме навсегда упокоенных от-обособленных единиц. Идеи застывают в идеоЛогиях, где господствует «логизм» их прилежной верности («истине») группе и ее вождю.

В 1823/24 гг. Любовь с Ольгой обернется катастрофой, а «свободы сеятель пустынный» осознает, что вышел «рано, до звезды» - в антропоэзисе Пушкина начнется труднейший этап проверки жизнестойкости Знамения «Любви-Свободы».

$* * * * * * * * * * * * * * * * * * * * * * * * * * * * * * * * * * * * * * * * * * * * * *$

1825, декабрь. Узнав о смерти Александра I, ссыльный Пушкин поехал в Петербург, на квартиру Кондратия Рылеева. Кабы доехал - принял участие в «несчастном восстании» и жизнь его резко свернула на трагическую стезю с вполне реальным обрывом на виселице. Но он, «суеверный» (и зарекшийся от бреда радикального либерализма два года назад) вернулся в Михайловское. Размышляя о роли Случая в людской истории лицейский №14 13 и 14 декабря (о восстании на Сенатской площади не знал, может догадывался) на одном дыхании написал легкую шаловливую поэму «Граф Нулин». За ничтожным анекдотом, приключившимся с новым Тарквинием в российской глуши полным-полно глубинных смыслов. Например, быстрое подведение по горячим следам итогов закончившего царствования: нуль. Какими прекрасными днями оно начиналось! Куда, куда Вы столь бесславно удалились?

Это и многое другое неоднократно выявлялось и обсуждалось. Я же все о своем: предлагаемая версия 


\section{Филология: научные исследования 2 (10) • 2013}

«утаенной любви» не может не заострить внимания на дате создания поэмы о Случае. Она родилась к 7 годовщине рисунка «Поцелуй», запечатлевшего клятву верности в Любви. Если бы Ольга поступила как Наталья Павловна (пощечина не обязательна), если бы Александр был влюблен как граф-вертопрах, если бы только волочился и приволакивался за всеми хорошенькими гуляка праздный... Тогда была бы совсем другая история, да не история вольнолюбивого невольника чести.

\section{Список литературы:}

1. Денисенко С.В., Фомичёв С.А. Пушкин рисует. Графика Пушкина. СПб.: НОТА БЕНЕ; Нью-Йорк: Туманов \& K, 2001.

2. Жуйкова Р.Г. Портретные рисунки Пушкина. Каталог атрибуций. СПб., 1996.

3. Летопись жизни и творчества Александра Пушкина. В 4-х тт. / Сост. Н.А. Тархова. М.: Слово, 1999.

4. Пушкин А.С. Большое академическое собрание сочинений: в 16 т. Т. 18, дополнительный. Рисунки. М.: Воскресенье, 1996.

5. Пушкин А.С. Полное собр. соч.: в 20 т. СПб.: Наука, 1999-2004.

6. Утаённая любовь Пушкина: сборник. СПб.: Академический проект, 1997.

\section{References (transliteration):}

1. Denisenko S.V., Fomichev S.A. Pushkin risuet. Grafika Pushkina. SPb.: NOTABENE; N’yu-York: Tumanov \& K, 2001.

2. Zhuykova R.G. Portretnye risunki Pushkina. Katalog atribuciy. SPb., 1996.

3. Letopis' zhizni i tvorchestva Aleksandra Pushkina. V 4-h tt. / Sost. N.A. Tarhova. M.: Slovo, 1999.

4. Pushkin A.S. Bol'shoe akademicheskoe sobranie sochineniy: v 16-ti t. Tom 18, dopolnitel'nyy. Risunki. M.: Voskresen`e, 1996.

5. Pushkin A.S. Polnoe sobranie sochineniy v 20 tomah. SPb.: Nauka, 1999-2004.

6. Utaennaya lyubov' Pushkina: sbornik. SPb.: Akademicheskiy proekt, 1997. 